thirty clear cases of diet deficiency. The basis of their diet was rice which contained $75 \%$ carbohydrates, $8 \%$ protein and $1 \%$ fat. Fish represented the main protein constituent, in the seasons when fresh fish was not available, fermented fish, shrimp paste or dried salt fish was consumed. The protein content of fermented fish and shrimp paste was $18 \%$ and $23 \%$, respectively, and the fat content $6 \%$ and $3 \%$, respectively. Insects have quite a high protein content. An analysis of three specimens of the spider, Melopoeus albostriatus Sim., carried out for me at the Government Laboratory in Bangkok gave a protein content of $63.4 \%$ and a fat content of $9.8 \%$.

In I93 I I found that Siamese resident in Bangkok knew little about the diet of the peasant and, moreover, that Siamese and Laos were somewhat reluctant to speak of their insect diet until they felt sure the information was not sought in order to label them as 'dirty feeders'. My inquiries led me to believe that insects were eaten more extensively perhaps than in any other country, that they were not infrequently eaten in bulk and that they had to be regarded as at least one of their lesser foods rather than merely as a 'relish' or flavouring to the otherwise limited menu.

A fuller discussion of the use of insects and invertebrates in Siamese diets will be found in a paper by Bristowe (1932).

In conclusion I ought perhaps to express my opinion that a demand for an insect diet in Britain is unlikely to develop and that I hope it will never be necessary even though the flavour of some insects would be found to be not unpleasant.

\title{
REFERENCES
}

Bristowe, W. S. (1932), Trans. R. ent. Soc. Lond. 80, 387.

Watson, (1760). Lectures on the Principles and Practice of Physics.

Zimmermann, C. (I931). Siam Rural Economic Survey, I93o-193I. Bangkok: Siamese Ministry of Commerce and Communications.

\section{The Indigenous Foods of Mexico and Central America}

\author{
By F. Aylward, Department of Food Technology, Borough \\ Polytechnic, London, S.E.I
}

\section{Introduction}

The primary purpose of this paper is to review the work carried out by Professor Robert Harris and his colleagues (of the Massachusetts Institute of Technology) who for the past 8 years have been investigating the composition and nutritive value of the foods of Mexico and Central America. Before considering in detail the programme of the Massachusetts group it may be useful, however, to outline the historical and geographical setting in which current investigations must be placed.

Central America in the strict geographical sense embraces all those countries (see Table I) lying between the southern borders of Mexico and the northern 
Table I. Food composition surveys in Mexico and Central America

\begin{tabular}{|c|c|c|c|c|}
\hline \multirow[b]{2}{*}{ Country } & \multicolumn{2}{|c|}{ Regions examined } & \multicolumn{2}{|r|}{ Food analysis } \\
\hline & $\begin{array}{l}\text { Area (Iooo } \\
\text { sq. miles) }\end{array}$ & $\begin{array}{r}\text { Population } \\
\text { (thousands) }\end{array}$ & $\begin{array}{l}\text { No. of } \\
\text { plants } \\
\text { analysed }\end{array}$ & Reference \\
\hline Mexico & 760 & 25,564 & 112 & $\begin{array}{l}\text { Cravioto, Lockhart, Anderson, Miranda \& } \\
\text { Harris (1945) }\end{array}$ \\
\hline Honduras & 44 & 1,534 & $12 \mathrm{I}$ & $\begin{array}{l}\text { Munsell, Williams, Guild, Troescher, Night- } \\
\text { ingale \& Harris (1949) } \\
\text { Munsell, Williams, Guild, Kelley \& Harris } \\
\text { (I950) }\end{array}$ \\
\hline Guatemala & 45 & 2,787 & $\begin{array}{l}124 \\
106\end{array}$ & $\begin{array}{l}\text { Munsell, Williams, Guild, Troescher, Night- } \\
\text { ingale \& Harris (I95०a). } \\
\text { Munsell, Williams, Guild, Troescher, Night- } \\
\text { ingale \& Harris (r95०b). }\end{array}$ \\
\hline E1 Salvador & 13 & 1,858 & $\begin{array}{r}194 \\
79\end{array}$ & $\begin{array}{l}\text { Munsell, Williams, Guild, Troescher, Night- } \\
\text { ingale, Kelley \& Harris (1950). } \\
\text { Munsell, Williams, Guild, Kelley, McNally } \\
\text { \& Harris (1950b) }\end{array}$ \\
\hline Nicaragua & 57 & 1,053 & $5 \mathrm{I}$ & $\begin{array}{l}\text { Munsell, Williams, Guild, Troescher \& } \\
\text { Harris (I950). }\end{array}$ \\
\hline Panama & 28 & 801 & 4 & $\begin{array}{l}\text { Munsell, Williams, Guild Troescher \& } \\
\text { Harris (1950) }\end{array}$ \\
\hline Costa Rica & 23 & 800 & I 54 & $\begin{array}{l}\text { Munsell, Williams, Guild, Kelley, McNally } \\
\text { \& Harris (I95०a). }\end{array}$ \\
\hline
\end{tabular}

borders of Columbia ; it includes also the Caribbean Islands which to the early explorers constituted the emerald necklace of the Antilles. These islands (among which are the British West Indies) differ from the continental mainland in a number of respects; in particular their economic and agricultural patterns have been affected by the development of plantation crops ; they will therefore be omitted from this survey.

Mexico, on the other hand, although regarded geographically as America del Norte may be grouped with the countries of Central America because of historical, political and linguistic similarities which are reflected in the lives and habits of the inhabitants.

\section{The Food habits of the American Indian}

The term indigenous requires definition. For a century and longer, botanists and zoologists have endeavoured to trace the authentic origins of the food plants and animals of the world and, although they have called to their aid the archeologist and anthropologist and the writings and pictorial records of early explorers, there are many unproven hypotheses. It would be unprofitable here to discuss the controversies regarding the possible contacts between the American continents and other regions before 1492 when Columbus arrived in the Bahamas, and it is proposed therefore to regard as indigenous those plants and animals known in Central America at that time and described by the early Spanish explorers, whose records give accounts of the life and customs of the Aztecs, Mayas and other Indian tribes. 
Even in these there is ground for debate, because at an early date the Spaniards conducted a two-way traffic between Asia (the Philippines) and Europe across the Mexican mainland, thus cutting short the long sea journey around the Cape of Good Hope. Thus an intermingling took place in Mexico itself and further confusion results because of the rapidity with which plants from the Americas were acclimatized in both Europe and Africa. Typical of a complex history is that of the ordinary (so-called Irish) potato, indigenous to Central America which reached the English colonies of North America by way of Europe, i.e. after a double Atlantic crossing.

Vaillant (1950, p. 28) in his review asserts that no plant cultivated by the (American) Indians was known in Asia, Europe or Africa before the first white settlement of the Americas, and that the introduction by the Spaniards of the food plants they found in Central America more than doubled the available food supplies of Europe. This claim, although difficult to prove, is an indication of the impact in the sixteenth century of the New World on the Old.

\section{Variety of Indian foods}

All the early observers were agreed that the Indians made use of a very large number of different foods. Prescott's (1949, p. 289) account of the daily repast of the Aztec Emperor (who unwillingly welcomed Cortes to Mexico City) refers to the hundreds of dishes set before him ; although lesser men lived on a simpler scale, there is no doubt about the variety available as is evidenced from the descriptions of the typical Indian markets and from the statements that the Indians would eat almost anything-all animal products of land, sea or lake, and almost all fleshy roots and seeds.

Some of the foods described by the Spaniards are listed in Table 2; they include maize, (Indian corn), a large number of root crops (including manioc or cassava), many varieties of beans, squashes, seeds and berries. Foods of animal

\section{Table 2. Some food plants known in the Americas before 1492}

\begin{tabular}{|c|c|c|c|}
\hline $\begin{array}{l}\text { Cereals } \\
\text { Legumes or pulses }\end{array}$ & $\begin{array}{l}\text { Maize } \\
\text { Kidney bean } \\
\text { Many other varieties of bean }\end{array}$ & Fruit vegetables & $\begin{array}{l}\text { Avocado or alligator pear } \\
\text { Pumkins } \\
\text { Squashes }\end{array}$ \\
\hline Nuts & Cashew nuts & & Tomato \\
\hline & Many other varieties & Fruits & Guava \\
\hline Earth vegetables: & & & Pineapple \\
\hline Roots & $\begin{array}{l}\text { Sweet potato } \\
\text { Yams }\end{array}$ & Spices and flavours & $\begin{array}{l}\text { Capsicums (peppers and chilis) } \\
\text { Vanilla }\end{array}$ \\
\hline $\begin{array}{l}\text { Underground } \\
\text { stems }\end{array}$ & $\begin{array}{l}\text { Manioc (cassava) } \\
\text { Potato } \\
\text { Jerusalem artichoke }\end{array}$ & Beverage plants & Cacao \\
\hline
\end{tabular}

origin appear to have been more limited in that the Indian knew none of the domesticated animals characteristic of Europe, and in fact had few domesticated animals apart from the turkey and a breed of dog. For animal food he relied largely on game and on fish, although the early records refer also to a minor source of animal 
food, namely an insect - the maguey slug-still known as a delicacy on the Mexican table (Vaillant, 1950, p. I35). Of the many foods given in Table 2 a few are selected for comment.

Maize and its products. The staple crop of Central America and Mexico is maize from which comes the daily bread of the Indians-the tortilla-a flat cake of unleavened corn meal. It is prepared by a relatively complicated process which is described by Cravioto, Anderson, Lockhart, Miranda \& Harris (r945).

The maize is suspended in two parts of $1 \%$ lime solution and heated to about $80^{\circ}$ for $20-45 \mathrm{~min}$; the mixture is then allowed to stand until the following day. The liquid is decanted off and the solid washed two or three times with water. The treated maize at this stage is known as nixtamal. It is finely ground by hand on a stone (metate) to give a pulverized solid (masa) which, in units of about $50 \mathrm{~g}$, is shaped into thin cakes ( $15-20 \mathrm{~cm}$ in diameter and $0.2 \mathrm{~cm}$ thick) and cooked on an iron plate. Modern variations include the use of power driven mills for grinding, and the sale of the prepared masa ready for baking. The essential details of tortilla making, including the lime process, go back to the pre-Columbian days, but the Indians baked the corn on clay instead of metal griddles, and it would appear that the earlier tortillas were much larger (about $40 \mathrm{~cm}$ in diameter).

Records are available (Vaillant, r950, p. I I6) of the ' recommended daily allowances' in the Aztec tribes : a child (after weaning at 3 years of age) was given half a tortilla a day ; from 4 to 5 years he was given one tortilla; from 6 to 12 years one and a half tortillas, and at 13 two tortillas.

Maize was put to other uses by the Indian; it formed the basis of the drink posole and the thin gruel atole, which with a tortilla may still be the main breakfast dish in many areas (Mason, I93I, p. 97). The stalks of the giant maize plant also yield a sugar which was highly esteemed by the early Indians who ' extolled the honey of the maize as equal to that of bees' (Prescott, 1949, p. 65). It was inevitable also that the maize should be used as a basis for an alcoholic preparation, chicha or maize beer.

Apart from maize, many other plants were employed by the Indian to give flour and bread, in particular a variety of nuts (such as chestnut, hazel-nut, acorns), and also in some areas, sunflower seeds which were also used as a source of edible oil. Several 'berry breads' are also described (cf. Mason, 1931, p. 85) including products in which strawberries, raspberries and huckleberries were combined with maize.

Root crops. The root crop manioc or cassava is now the great staple food of Brazil but is common also in Central America, and was widely used by the Indians, especially in those aresa where the climate was too hot for maize (Mason, I93 I, p. 91; Winton \& Winton, I932).

The plant (which gives us tapioca) was used in many ways, for example cassava bread was made by grating the root and squeezing in a type of basket press; the solid was then formed into cakes and well baked. A coarse powder formed by grating the root and drying in the sun is still prepared as it was in the time of 
Cortes, and the plant is also boiled and eaten as a vegetable. A minor use of the plant in some areas is in the production of a cassava beer.

A characteristic of the Indian was the attention paid to the cooking of food plants, and the presence of cooked foods in the city markets was commented upon by the Spanish writers. Thus the Indian was able to use plants which in the fresh state would be poisonous, and in this category are varieties of manioc, as well as wild varieties of the sweet potato, and both wild and cultivated yams.

Biochemical investigations have shown that the manioc root contains a cyanophoric glycoside (linamarin) and a corresponding enzyme (linase) which interact in the grated root to give hydrogen cyanide (Dunstan, Henry \& Auld, 1906; Armstrong \& Armstrong, I93 I). Similar poisonous principles have been isolated from other Central American food plants, and thus the attention paid by the Indian to the cooking process is fully justified.

Beverages. The cacao plant was employed by the Indian for the production of choclatl which was prepared in many forms and with many additions. It was a favourite beverage of the Aztec Emperors but was used outside court circles, and one Spanish chronicler reported that "it was so nutritious that a single cup was enough to sustain a soldier through the longest day's march' (Prescott, I949, p. 74).

The traditional alcoholic drink of the Mexicans is pulque (the octli of the Aztecs) which is prepared by the fermentation of the juice of the maguey, a cactus of the Agave family. This plant was put to other uses, (cf. Prescott, 1949, p. 65) ; its roots were eaten as a vegetable, its leaves provided a thatch for houses and were also used in the preparation of a paste and a type of paper.

The preparation of pulque has been described recently by Harris (I946) : when the cactus blooms, the Indian cuts out the blossoms to expose the central hollow chamber and returns day by day to collect the juice that has drained into this ; the juice is first stored in a pigskin bag and later in a vat when fermentation takes place. The resulting liquor (of alcoholic content about $4 \%$ ) is a moderately thick opaque liquid with an acid flavour similar to sour milk. Prescott (r949, p. 65) asserts that 'it requires time to reconcile Europeans to the peculiar flavour of this liquor, on the merits of which they are consequently much divided'. He adds 'there is but one opinion among the natives', and he comments also on the extensive use of pulque, the excise duties on which, before the revolution of 1828 , formed an important part of the crown revenues, the equivalent of $f^{250,000}$ was collected in one year from three of the cities of Mexico.

\section{Food and nutrition surveys}

The investigations of Harris and his colleagues began in 1944 and had a fourfold objective : ( 1 ) the collection and analysis of a large number of edible plants in Mexico and Central America ; (2) the examination of methods of food preparations and the determination of the composition of prepared foods ; (3) a survey of dietary habits ; and (4) a clinical and biochemical survey of nutritional states. 


\section{Collection of food plants}

Only sections of these projects have so far been accomplished, but all the work has been characterized by its thoroughness and by the range of analyses carried out over a very wide area, in that analytical data have been obtained on more than I500 samples representing some 250 varieties of plants distributed as shown in Table I. Although most of the plants examined were indigenous in the sense that has already been discussed, the survey included others of non-American origin, but which are now growing in the areas under examination.

A botanist, experienced in taxonomy, was responsible for the major part of the collection; he travelled long distances looking for food plants, whether growing wild or cultivated, and observed the foods that were being produced in the field, on sale at the markets and used in the home. Whenever possible, samples of plants were obtained directly from the field. Alternatively they were purchased from the growers immediately after harvesting or, if this was not feasible, they were obtained from the local market.

Comprehensive notes were made about each sample: the Spanish, English and scientific names, a detailed description accompanied by a colour photograph, records of the altitude, soil type and fertilizer treatment together with estimates of the rainfall in the area where the plant was grown. A description was also given of the local uses of the plant and a specimen of each was placed aside for detailed botanical identification. The complete collection is now available as a permanent record of the work.

In many instances several samples of the same species of plant were collected from different regions in a country. Thus in Guatemala the first group of 124 samples corresponded to forty-nine different foods; the second group of ro6 samples to fifty-two foods. When all the countries are considered together there is naturally further duplication which has had the advantage of providing information about variations in the composition of any one plant under different soil and climatic conditions.

\section{Food analysis}

Specimens of the edible parts of each plant were macerated and after treatment with suitable preservatives were despatched by air to the Massachusetts laboratories, where analyses were carried out for moisture, crude fibre, ether extract, nitrogen, phosphorus, calcium, iron, ascorbic acid, thiamine, riboflavin, nicotinic acid and vitamin $\mathrm{A}$ (as carotene). Control experiments established that no significant quantities of even the most unstable nutrient (ascorbic acid) were lost in the intervals between sampling and analysis. Special care was taken to detect possible analytical errors arising from the presence of interfering substances, a common problem in investigations on unusual materials.

The investigations on food composition had a threefold purpose : ( 1 ) to obtain sound analytical data on plants that had not been examined by earlier workers ; (2) to re-examine certain plants for which the data were doubtful or limited; 
(3) to compare the composition of certain plants grown in Mexico and Central America with the established figures for similar species known in other areas. All these objects were realized as may be seen from the extensive findings published in a series of papers referred to in Table I. Moreover it was demonstrated that many of the plants examined, including species and varieties unknown as food sources in the United States or Europe, contained high levels of certain nutrients (Harris, I946, I952; Harris \& Munsell, 1950).

In the interpretation of such data, it is clearly necessary to take into account the amounts of different foods that are eaten per day, or that might be eaten if successfully introduced into the diet. A minor food eaten in relatively small quantities may be of importance because of some one constituent present in relatively high concentration. On the other hand, a staple food such as a cereal containing perhaps only small percentages of a particular nutrient may make an important contribution because of the total quantity of the staple consumed.

To illustrate the importance of information on the daily intake, two examples may be given from Central American foods. Certain varieties of chili are not only rich in ascorbic acid but may contain high levels of vitamin A (as carotene), the values varying between 8200 and 95,000 i.u./ $100 \mathrm{~g}$ with an average of 30,000 i.u./ I00 g. Thus in some rural areas in Mexico where the peasant consumes daily 40-60 $\mathrm{g}$ of chili, 12,000 or more i.u. of vitamin A may be provided from this source (Harris, 1945, 1946). A good source of minerals and certain vitamins is the uncultivated plant, Malva parviflora, the leaves of which are employed in some areas as a food, A daily serving of $100 \mathrm{~g}$ will supply $40 \%$ of the calcium, $90 \%$ of the iron, $14 \%$ of the vitamin $\mathrm{A}, 60 \%$ of the ascorbic acid, and a significant amount of the thiamine and nicotinic acid required by the adult man on the basis of recommended allowances of the (U.S.A.) National Research Council (I945).

Detailed examination of the analytical figures showed that in a number of instances a variety of a given plant in Mexico or Central America was higher in nutritive value than a corresponding variety in the United States, the difference arising no doubt both from variations in the genetical strain and from conditions of soil and climate. The figures revealed also the differences that occur from one sample of a plant to another in one country, and illustrate the difficulties of using standard tables of food composition based on investigations of plants grown in temperate zone. It is clear that in some cases at least such data cannot be used for the calculation of tropical and semi-tropical diets without the possibility of significant errors.

Harris (1948) has examined the individual nutrients obtained from food plants and using an arbitrary base-line for each (see Table 3 ) has shown that in many respects the foods of Central America compare very favourably with those of the United States.

\section{Prepared foods}

The survey of the composition of crops was extended by Harris and his colleagues to include studies of prepared food, and although these are by no means complete, information of value has already been obtained. 
Table 3. Comparison of food plants in Central America and the United States in terms of arbitrary standards for certain nutrients. Figures based on comparison of analytical data in publications of the United States Department of Agriculture (Anonymous, 1945 ; Chatfield \& Adams, 1940) and data obtained in the Nutritional Laboratories of the Massachusetts Institution of Technology

\begin{tabular}{|c|c|c|c|c|}
\hline & \multirow{2}{*}{$\begin{array}{c}\text { Arbitrary } \\
\text { standard } \\
\text { minimum } \\
\text { value as basis } \\
\text { of compari- } \\
\text { son }(\mathrm{mg} / \mathrm{lo0} \mathrm{g})\end{array}$} & \multicolumn{2}{|c|}{$\begin{array}{l}\text { No. of food plants above } \\
\text { minimum value }\end{array}$} & \multirow{2}{*}{$\begin{array}{c}\text { No. of } \\
\text { Central } \\
\text { American } \\
\text { food plants } \\
\text { above U.S } \\
\text { maximum } \\
\text { value }\end{array}$} \\
\hline & & United States & $\begin{array}{l}\text { Central } \\
\text { America }\end{array}$ & \\
\hline Nitrogen & $2500 \cdot 0$ & 8 & 20 & I \\
\hline Calcium & 100.0 & 12 & 39 & 6 \\
\hline Iron & $3 \cdot 0$ & 19 & 51 & 10 \\
\hline Carotene & $2 \cdot 0$ & 14 & 32 & 3 \\
\hline Thiamine & 0.2 & 16 & 42 & 5 \\
\hline Riboflavin & 0.2 & 13 & 34 & I \\
\hline Nicotinic acid & 2.0 & 13 & 31 & 0 \\
\hline Ascorbic acid & 75.0 & 7 & 48 & 20 \\
\hline
\end{tabular}

In spite of the importance of the tortilla in the Mexican diet, little previous work had been carried out on its composition. The results obtained by the Massachusetts school (Cravioto, Anderson et al. 1945) are summarized in Table 4 and show that during the processing of maize into the tortilla, some losses occur in

Table 4. Changes in mineral and vitamin content during preparation of tortilla (All values expressed as $\mathrm{mg} / \mathrm{roog}$ dry weight)

\begin{tabular}{|c|c|c|c|c|c|}
\hline \multirow[b]{2}{*}{ Nutrient } & \multicolumn{4}{|c|}{ Stages in preparation } & \multirow{2}{*}{$\begin{array}{l}\text { Amount of } \\
\text { daily diet } \\
\text { derived } \\
\text { from } 300 \mathrm{~g} \\
\text { tortilla (wet } \\
\text { basis) (mg) }\end{array}$} \\
\hline & $\begin{array}{c}\text { Initial, } \\
\text { maize }\end{array}$ & $\begin{array}{l}\text { After lime } \\
\text { treatment, } \\
\text { nixtamal }\end{array}$ & $\begin{array}{l}\text { After } \\
\text { grinding, } \\
\text { masa }\end{array}$ & $\begin{array}{c}\text { After } \\
\text { baking, } \\
\text { tortilla }\end{array}$ & \\
\hline Calcium & 9 & 169 & 190 & 190 & 333 \\
\hline Phosphorus & 275 & 294 & 305 & 317 & $55^{2}$ \\
\hline Iron & $2 \cdot 7$ & $3 \cdot 3$ & $3 \cdot 6$ & 3.7 & 6.6 \\
\hline Carotene & 0.18 & 0.15 & 0.15 & 0.10 & 0.18 \\
\hline Thiamine & 0.39 & 0.35 & 0.37 & 0.33 & 0.57 \\
\hline Riboflavin & 0.09 & 0.10 & 0.10 & 0.10 & 0.18 \\
\hline Nicotinic acid & $1 \cdot 90$ & 1.80 & $1 \cdot 72$ & 1.67 & 2.88 \\
\hline
\end{tabular}

carotene, nicotinic acid, thiamine, and some gain in iron. The most significant observation, however, was the twentyfold increase in the calcium of the tortilla compared with the initial grain, resulting from the lime treatment.

The average daily consumption of tortilla is of the order of $280 \mathrm{~g}$. Among the poorer groups in some areas it may be as high as $700 \mathrm{~g}$, and thus the tortilla is an 
important source of both calories and minerals, and is a by no means negligible source of some of the vitamins. The daily contribution from the tortilla of $0.3 \mathrm{~g}$ or more calcium explains how the Mexican Indians can achieve an adequate calcium intake, and this is not only interesting in itself as a demonstration of the importance of local custom, but provides striking testimony of the false conclusions that may be drawn from a survey which considers only the sources of food without inquiry into the methods of preparation.

Among the prepared foods analysed (Cravioto, Lockhart et al. 1945) was pulque which was found to contain significant amounts of protein, thiamine $(0.20 \mathrm{mg} / \mathrm{ro0}$ $\mathrm{ml}$.$) , nicotinic acid (0.30 \mathrm{mg} / 100 \mathrm{ml}$.) and ascorbic acid $(6.2 \mathrm{mg} / \mathrm{r} 00 \mathrm{ml}$.$) , and these$ figures taken in conjunction with the 7 -day diet records of a group of 100 Otomi Indians had led Harris (1946) to the conclusion that in this group the pulque ranks next to the tortilla as the most important item in the dietary. Testimony to the nutritional contribution of pulque is also provided by the report (Chase, r93 I) that at one time an attempt was made to prohibit the manufacture of the drink, but the ban had to be removed because of the illnesses that resulted in certain rural communities.

\section{Nutrition surveys}

A detailed discussion of the clinical and biochemical surveys of nutritional status in Mexico and Central America is outside the scope of this paper, but reference must be made to two series of investigations in Mexico, the first undertaken by the Massachusetts group in conjunction with physicians in Mexico City, the second by a group under the aegis of the International Health Division of the Rockefeller Foundation.

In the first survey 1000 Mexican City schoolchildren were examined by a research team that had previously completed a survey of 760 middle class children in Michigan ; the surprising conclusion was reached (Lockhart, Miranda \& Harris, 1946; Harris 1946) that the poverty-stricken Mexican children showed evidence of a nutritional status superior in most respects to that of the American children.

The results of the other surveys also pointed in the same direction; they included six very thorough studies on large numbers of individuals and families living in cities (Robinson, Payne \& Calvo, I944; Calvo, Serrano, Millan, Miranda \& Anderson, 1946; Anderson, Robinson, Calvo, \& Payne, 1946) and in rural areas (Anderson, Calvo, Serrano \& Payne, 1946). Especially striking is the report on the Otomi Indians living at an altitude of $6500 \mathrm{ft}$. in four villages in the Mezquital Valley (75 miles north of Mexico City) described as 'unquestionably one of the poorest areas of the country'. The Indians (whose diet included unusual vegetable foods and liberal amounts of pulque) showed little clinical evidence of malnutrition and they had higher levels of serum ascorbic acid than any other Mexican group examined. A 7 -day diet survey demonstrated that the intake of both vitamin $A$ and ascorbic acid was excellent and it was evident that pulque was being used not only as a source of water but also of various nutrients. 
The other five surveys gave not dissimilar findings (summarized by Anderson, Calvo, Robinson, Serrano \& Payne, 1948). 'Clinical evidences of nutritional deficiencies were uncommon in the population groups studied, but there were indications of mild deficiencies, particularly of lack of vitamin B-complex', but no cases of clinical rickets were observed and no cases of pellagra. These clinical observations were supported by biochemical tests.

\section{DISCUSSION}

The American clinical workers present a more optimistic picture of the nutritional state of the people of Mexico than might have been expected, and although no one would deny that improvements are possible, it is evident that the groups examined are living on diets that are fairly well balanced in respect of the proteins, minerals and vitamins although the total amount of food available may be inadequate.

Harris and his colleagues believe that their research on the composition of foods taken in conjunction with the nutrition surveys points to the conclusion that many countries should be able to improve nutritional standards, to promote a positive health policy and even to maintain a larger population, on the basis of improvements in agriculture leading to the greater production of crops of special value (Harris, 1946, 1952).

Much remains to be done in Mexico and Central America to correlate and to extend clinical and laboratory investigations. The analytical work so far undertaken is to be regarded as exploratory in nature, preliminary to the more detailed examination of selected crops, the determination of the biological values of the proteins available in the crops and the assessment of the relative quantities of fats, carbohydrates and proteins that can be obtained from the sources available and included in a diet of adequate calorie content.

The Massachusetts programme sprang from private initiative with the support of the W. K. Kellogg Foundation and the United Fruit Company, and in collaboration with the Pan American Sanitary Bureau. The results obtained have led to a new outlook on nutritional problems in the countries concerned; in Mexico City, food analysis laboratories have been established at the National Institute of Nutrition, while in Guatemala City an Institute of Nutrition of Central America and Panama has been created with central laboratories to serve all the countries of the region.

It is not possible here to discuss the relevance of the results obtained in Mexico and Central America to the nutrition problems of British colonial territories; the importance of the indigenous foods of Africa and Asia has already been considered at symposia of this Society and has been reviewed elsewhere (Aylward, I95I).

\section{REFERENCES}

Anderson, R. K., Calvo, J., Robinson, W. D., Serrano, G. \& Payne, G. C. (I948). Amer. F. Publ. Hlth, $38, \quad 1126$.

Anderson, R. K., Calvo, J., Serrano, G. \& Payne, G. C. (1946). Amer. F. Publ. Hlth, 36, 883. 
Anderson, R. K., Robinson, W. D., Calvo J. \& Payne G. C. (1946). F. Amer. diet. Ass. $22,588$.

Anonymous (1945). Misc. Publ. U.S. Dep. Agric. no. 572.

Armstrong, E. F. \& Armstrong, K. F. (193I). The Glycosides. London: Longmans Green.

Aylward, F. (195 r). Nature, Lond., 168, 1100.

Calvo, J., Serrano, G., Millan, R. S., Miranda, F. de P. \& Anderson, R. K. (1946). F. Amer. diet. Ass. 22, 297.

Chase, S. (1931). Mexico, A Study of Two Americas. London : Macmillan and Co.

Chatfield, C. \& Adams, G. (1940). Circ. U.S. Dep. Agric. no. 549.

Cravioto, R. B., Anderson, R. K., Lockhart, E. E., Miranda, F. de P. \& Harris, R. S. (1945). Science, I02, $9 \mathrm{r}$.

Cravioto, R. B., Lockhart, E. E., Anderson, R. K., Miranda, F. de P. \& Harris, R. S. (1945). $\mathcal{F}$. Nutr. 29, 317.

Dunstan, W. R., Henry, T. A. \& Auld, S. J. M. (1906). Proc. roy. Soc. B. 78, I52.

Harris, R. S. (1945). Science, ro2, 42 .

Harris, R. S. (1946). F. Amer. diet. Ass. 22, 974.

Harris, R. S. (1948). Nutr. Rev. 6, 33.

Harris, R. S. (1952). Int. Z. Vitaminforsch. 23, 405.

Harris, R. S. \& Munsell, H. E. (1950). F. Home Econ. 42, 629.

Hill A. F. (I937). Economic Botany. London : McGraw Hill Book Co.

Lockhart, E. E., Miranda, F. de P. \& Harris, R. S. (1946). Fed. Proc. 5, 235.

Mason, G. (193I). Columbus Came Late. London: The Century Co.

Munsell H. E., Williams, L. O., Guild, L. P., Kelley, L. T. \& Harris, R S (1950). Food Res, I5, 42r.

Munsell H. E., Williams, L. O., Guild, L. P., Kelley, L. T., McNally A. M. \& Harris, R. S. (I950). Food Res. 15, 379.

Munsell, H. E., Williams, L. O., Guild, L. P., Kelley, L. T., McNally, A. M. \& Harris, R. S. (1950b). Food Res. 15, 439.

Munsell, H. E., Williams, L. O., Guild, L. P., Troescher, C. B. \& Harris, R. S. (1950). Food Res. I5, 355 .

Munsell, H. E., Williams, L. O., Guild, L. P., Troescher, C. B., Nightingale, G. \& Harris, R. S. (I949) Food Res. 14, 144.

Munsell, H. E., Williams, L. O., Guild, L. P., Troescher, C. B., Nightingale, G. \& Harris, R. S. (I950a). Food Res. 15, 16.

Munsell, H. E., Williams, L. O., Guild, L. P., Troescher, C. B., Nightingale, G. \& Harris, R. S. (1950b). Food Res. $15,34$.

Munsell, H. E., Williams, L. O., Guild, L. P., Troescher, C. B., Nightingale, C., Kelley, L. T. \& Harris, R. S. (1950). Food Res. 15, 263.

National Research Council (1945). Rep. Nat. Res. Coun., Wash., no. 122.

Prescott, R. (1949). Conquest of Mexico. London : Allen \& Unwin.

Robinson, W. D., Payne, G. C. \& Calvo, J. (1944). F. Amer. diet. Ass. 20, 289.

Vaillant ,G. C., (1950). The Aztecs of Mexico. London : Penguin Books Ltd.

Winton, A. L. \& Winton, K. B. (1932). The Structure and Composition of Foods, Vol. I. London : Chapman \& Hall Ltd.

\title{
The Food of the Australian Aboriginal
}

\author{
By G. H. Bourne, Department of Histology, \\ London Hospital Medical College, Turner Street, London, E.I.
}

The Australian aboriginal is, at least from a cultural point of view, a stone-age man. That is to say, he is a nomadic hunter and makes no attempt to cultivate the ground and to make permanent camps or settlements in any one place.

A tribe will occupy an area of country until it is denuded of food and will then move on to a fresh region. In some areas food may be so plentiful that a tribe may remain there for some considerable time. 